\title{
THE ABILITY OF TOURIST NATURAL TRAILS TO RESIST TOURISM LOAD AND POSSIBILITIES FOR REDUCING THE ENVIRONMENTAL IMPACTS: CASE STUDY OF THE SLOVAK PARADISE NATIONAL PARK (SLOVAKIA)
}

\author{
JANA JANOČKOVÁ, MÁRIA KOŠČOVÁ, JANA JABLONSKÁ
}

Technical university of Košice, Faculty of Mining, Ecology, Process Control and Geotechnologies, Institute of Geotourism, Letná 9, 04200 Košice, Slovak Republic; e-mail: maria.koscova@tuke.sk

\begin{abstract}
Janočková J., Koščová M., Jablonská J.: The ability of tourist natural trails to resist tourism load and possibilities for reducing the environmental impacts: case study of the Slovak Paradise National Park (Slovakia). Ekológia (Bratislava), Vol. 34, No. 3, p. 281-292, 2015.

The strictly protected natural area of Suchá Belá Gorge, located in the Slovak Paradise National Park, Slovakia, is exposed to environmental degradation by heavy tourist loads. Although educational and technical measures have been put in place, there is ongoing debate whether and how to limit the intensity of tourist visits. This study evaluates the ability of the trail leading through the gorge to resist trampling disturbance and to minimise the environmental impacts in the wider area of Suchá Belá by keeping tourists from moving off the designated areas. Aspects of trail layout, geological and geomorphological structures, terrain altering during the summer season, and acceptable tourist flow were investigated. The results show the current development would be acceptable in the case of limited off-trail movement. It therefore seems appropriate to review the trail allocation and marking, and to focus on environmental education rather than on limiting tourist visits.
\end{abstract}

Key words: environmental impacts, tourism, tourist trails, national parks, Slovakia.

\section{Introduction}

As the recreation and commercial development of a national park often come second to resource protection, park use and preservation often appear contradictory and can result in management challenges. Although restricted, the activities of tourism and recreation pose main threats to national parks in Slovakia, followed by factors of incorrect forest management, conversion of land use (building and infrastructure development), hunting, and poaching (World Wildlife Fund, 2004).

The gorge Suchá Belá is due to its unique natural value graded the highest protection level by the state, permitting solely the activity of walking on the designated trail leading through the gorge. However, the specifics of the terrain layout along with the tourist load and tourist behaviour result in increased geohazard activity (erosion, rock fall, rock sliding, weathering), development of undesirable trails, and negative impacts on vegetation (State 
Nature Conservancy - Slovak Paradise National Park Administration, 2008). Minimising the impacts on nature has been aimed for by terrain adjustments and distribution of educational material, yet ongoing devastation of the area has raised a debate whether it would be suitable to limit the number of tourist visits. Such an issue is often addressed by carrying capacity assessment (CCA), in generic terms stating how many people can be permitted into a site without degrading the site or the visitor experience (Coccossis, Mexa, 2002; IUCN, CORDIO, and ICRAN, 2008; Sayan, 2011). In Slovakia, the CCA has revolved around evaluating site use by the assessment of abiotic complexes in extensive study areas (e.g., Drdoš, 1990; Midriak, Tomagová-Rendeková, 1993; Hrnčiarová, 2000; Hrnčiarová et al., 2002). The focus on large scale of impacts in extensive areas did not allow for specification, but created an orientation scheme for general land use. The more specific studies analysed impacts of tourism on tourist trails and their immediate natural surroundings (e.g., Hrnčiarová, Altmanová, 1999; Midriak et al., 1992; Barančok, 1996). By reviewing these studies, Barančok and Barančoková (2008) created an evaluation scheme to assess tourist trail carrying capacity by quantifying a set of tourist path properties (inclination of the tourist path, inclination of the terrain relief, resistance of rocks, soil erodibility, type of path surface, potential for leaving the path, damage to the surrounding vegetation, evaluation of potential erosion, and evaluation of resistance). They also calculated a tolerable daily turnout based on the length and width of the path, duration of ascent in minutes, duration of start hike in minutes, and attendance. Based on these evaluations, the authors determined a scale for path carrying capacity.

Internationally, only three studies were found to deal with the degradation of natural tourist trails by hiking (Bielawska, Tsermegas, 2009), and by hiking and biking (Marion, Wimpey, 2007; Thurston, Reader, 2001). The researchers evaluated, similarly to studies in Slovakia, the geomorphology and geology of the site and the anthropogenic impacts on the trail surface, yet with the difference of not concluding the resistance of tourist trail by quantifying the factors. These studies found that in the degradation of the trail and its surroundings, the number of tourists to the site is irrelevant in comparison to the relation of the path to the forms of relief, ground character, and the meteorological phenomena.

The above-mentioned studies all conclude that an appropriate tourist trail (by surface and layout) is able to absorb and suitably distribute tourist impacts. Therefore, the trail leading through the Suchá Belá Gorge has to be recognised for its importance in minimising the environmental impacts in the wider area of Suchá Belá. Thus the main aim of this study is to specify the trail resistance and suitability of its arrangement by the evaluation of complex factors. These include factors from previously mentioned studies (geometric parameters, geological structure, observation of trail surface altering) complemented by site-specific characteristics that are perceived to determine the resistance level of the tourist trail and its natural surroundings (specific types of geohazard limiting trail outline and posing threat to environment and tourists, observation of the surrounding terrain up to $10 \mathrm{~m}$ from the trail, trail layout, and other factors that lead to off-trail movement of tourists).

\section{Study area}

The gorge Suchá Belá is located in the Slovak Paradise National Park (National Park Slovenský Raj), which covers an area of $197.63 \mathrm{~km}^{2}$ situated in eastern Slovakia (Fig. 1). 


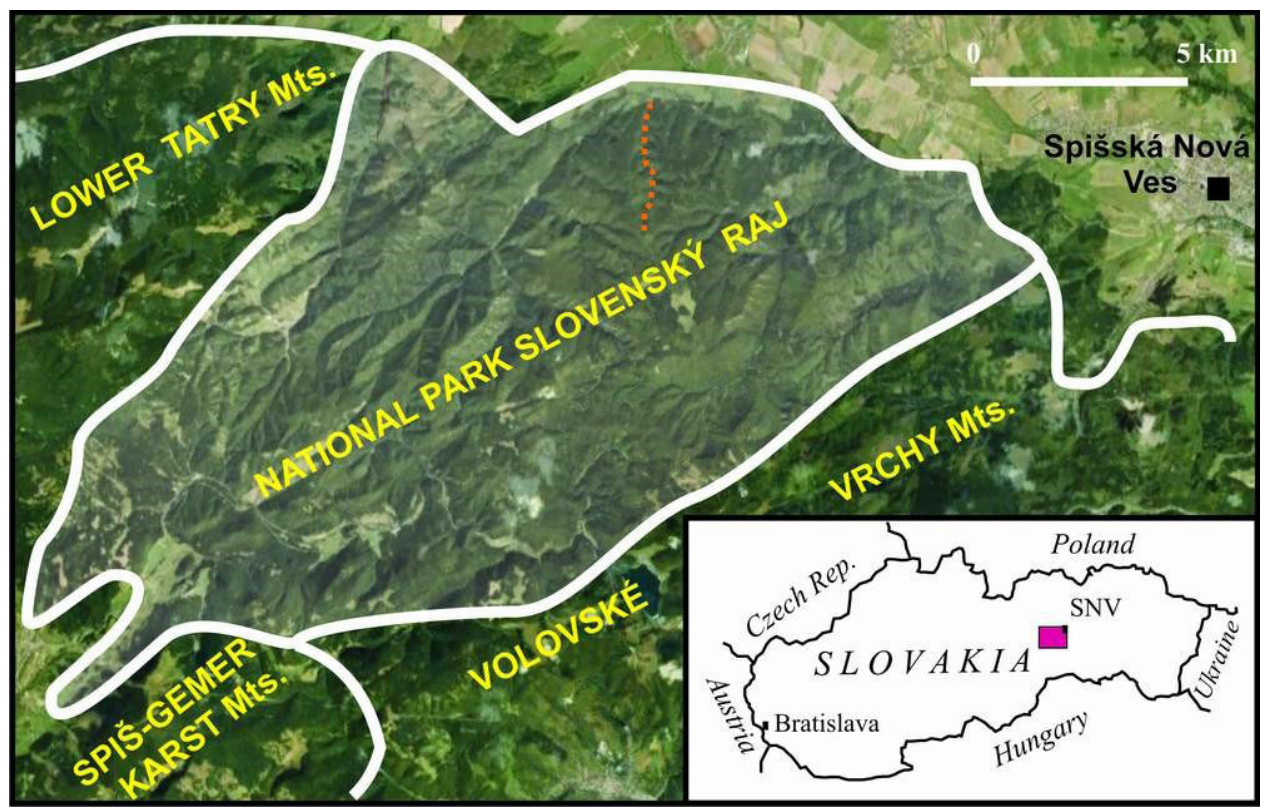

Fig. 1. Location of the study area, Suchá Belá (orange dotted line). The inserted map shows the position of the Slovak Paradise National Park (National Park Slovenský Raj; red square) in Slovakia.

The Suchá Belá Gorge is the most visited place in the national park, receiving daily over 1,000 tourists every summer (Slovak Paradise National Park Administration, 2012). The natural reserve of Suchá Belá is under the highest level of protection by the state, and is also designated as a protected area of European significance.

The gorge is $3.8 \mathrm{~km}$ long, with more than $400 \mathrm{~m}$ elevation difference throughout the route. The topmost point is $950 \mathrm{~m}$ above the sea level. The one-way trail passes through a demanding, highly dissected terrain along five waterfalls, rock archways, terraces, plunge pools, perpendicular rock ribs, and overhanging rock faces. Certain sections of the trail are secured by iron and wooden ladders, steps, chains, and bridges (Fig. 2). The vegetation profile of the gorge is determined by temperature inversion causing colder climate at lower elevations, and by a prevailing limestone occurrence, which builds up the wider surroundings of the path. Valuable rock, wetland, and forest habitats are in direct contact with the tourist trail.

\section{Methods}

The resistance of the natural environment of the path and its adjacent terrain to tourist load was evaluated by examining the following interrelated factors: (a) trail geometric parameters (gradient of the tourist path and terrain relief fringing the trail), (b) geological structure (the rock resistance of the trail surface), (c) geomorphological structure (geohazard potential of the area bordering the trail), (d) morphologic alterations of the path and its surroundings associated with an increased visitation during the summer months, and (e) tourist flow to the site.

The trail leads through a varied terrain and was therefore divided into 13 independently assessed sections, each section constrained by ladders and/or bridges. The selected attributes were evaluated based on terrain observations since July 2012 and by a review of the literature, including geological maps and topographic tourist maps at the scale of $1: 25,000$.

The influence level of each criterion on trail resistance was expressed by a weight coefficient chosen arbitrarily in the range from 0.1 (the least influence) to 1.0 (maximal influence). Grades on a scale from 1 (high resistance) to 5 (very low resistance) were assigned to the selected attributes for the particular sections of the trail (Tables 1-7). 


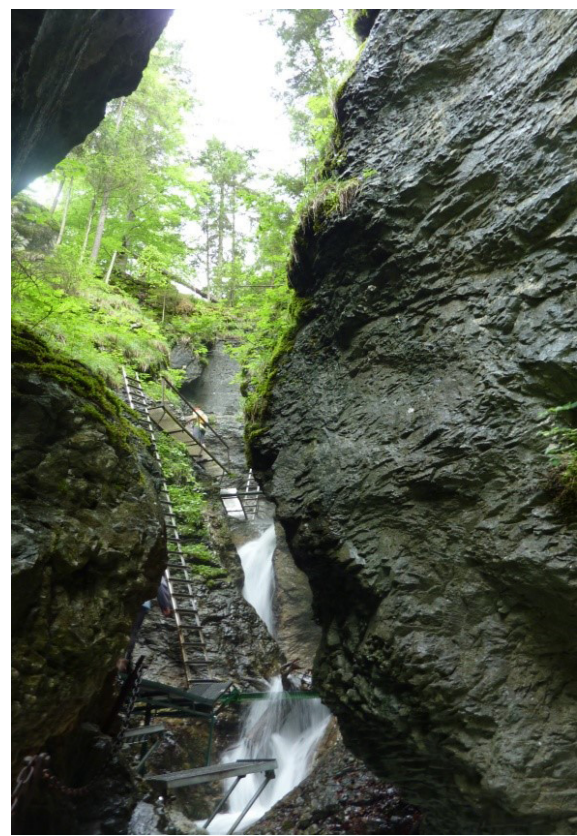

Fig. 2. The access equipment of the path.

(a) The geometric parameters of the trail (gradients of the trail and surrounding relief) were calculated from the map at scale 1:10,000. Each of the 13 sections represents autonomous parts of the trail with its own geometric characteristics. The calculation of the surrounding terrain gradient considered a terrain belt extending $20 \mathrm{~m}$ from the trail to both sides.

(b) The assessment of rock resistance considered factors of mechanical resistance and chemical resistance according to the classification of Klimaszewski (1981).

(c) The geohazard potential, referred to as the potential for the occurrence of a situation, which poses a level of threat to the environment or property with possible influence on the safety of tourists (UNESCO, IUGS, IGCP, 2011), was determined by mapping the occurrence of the four basic groups of hazards: rock erosion, rock fall, sliding, and weathering. The mapping was also complemented by data from the geological map of the Slovak Paradise (Mello et al., 2000). The areas with geohazard occurrence were located in the map of the trail and evaluated similarly to the previous parameter by five grades. The lowest grade (1) was given to the areas with very low geohazard potential, and the highest grade (5) was assigned to the areas with very high geohazard potential.

Each of the given criteria was assessed for individual trail sections by multiplying the assigned grade for the given criteria by its weight coefficient. In the assessment of trail resistance inclusive of all of the analysed factors, the section with the lowest resistance determined the particular resistance category to which Suchá Belá belonged, on a scale of 0.1 (multiplying the lowest possible weight coefficient with the lowest possible assignment grade) to 5 (multiplying the highest possible weight coefficient with the highest possible assignment grade) for five categories (very high resistance, high resistance, middle resistance, low resistance, and very low resistance; Fig. 3). Thus the trail resistance of Suchá Belá can, for the whole trail, be expressed by the following formula:

\section{$\operatorname{Tr}=C w X \max \times T S a X \max$}

where $\operatorname{Tr}$ is the trail resistance, $C w X$ max is the highest assigned weight coefficient for factor $\mathrm{X}$, and TSaXmax is the highest grade assigned for factor X.

(d) A suitable tourist flow was proposed in recognition of the influence that visit intensity has on factors of overcrowding and moving off the designated areas. The length and width of the tourist path, average duration of the hike, an appropriate distance between tourists, calculations of tourist visits, and most frequented hours of tourist visitation were investigated. The appropriate distance between tourists was considered for the whole length of the path, in a time reported for the hike duration. Such tourist flow was calculated for the most frequented time of visiting (between 8:00 and 16:00), formulated as:

$$
T f=\frac{V t[\text { hours }]}{T d[\text { hours }]} \times \frac{T l[\text { meters }]}{R d[\text { meters }]}
$$

where $T f$ is the optimal tourist flow, $V t$ is the period of maximum trail load, $T d$ is the duration of the hike, $T l$ is the trail length, and $R d$ is the recommended distance between tourists.

(e) The morphologic alterations of the trail and its surroundings linked with increased trampling disturbance were observed during two heavily visited months in the summer season (June and July 2012). The extent of surface alterations was concluded in correlation with the reported number of tourist visits (by the national park administration), which can be seen as one of the indicators for preservation of the site. 


\section{Results}

(a) Trail geometric parameters

Two different parameters characterising the geometry of the trail were analysed: gradient of the tourist path and gradient of the terrain fringing the path (Tables 1-3).

T a b l e 1. Categories of tourist path inclination.

\begin{tabular}{|c|c|l|}
\hline Weight coefficient & Category & \multicolumn{1}{c|}{ Assignment } \\
\hline \multirow{3}{*}{0.7} & $0-7^{\circ}$ & $1-$ very low inclination \\
\cline { 2 - 3 } & $7^{\circ} 1^{\prime}-12^{\circ}$ & $2-$ low inclination \\
\cline { 2 - 3 } & $12^{\circ} 1^{\prime}-17^{\circ}$ & $3-$ middle inclination \\
\cline { 2 - 3 } & $17^{\circ} 1^{\prime}-25^{\circ}$ & $4-$ high inclination \\
\cline { 2 - 3 } & over $25^{\circ}$ & $5-$ very high inclination \\
\hline
\end{tabular}

$\mathrm{T}$ a b l e 2. Categories of inclination of the terrain relief fringing the path.

\begin{tabular}{|c|c|l|}
\hline Weight coefficient & Category & \multicolumn{1}{c|}{ Assignment } \\
\hline \multirow{3}{*}{0.5} & $0-7^{\circ}$ & $1-$ very low inclination \\
\cline { 2 - 3 } & $7^{\circ} 1^{\prime}-12$ & $2-$ low inclination \\
\cline { 2 - 3 } & $12^{\circ} 1^{\prime}-17^{\circ}$ & $3-$ middle inclination \\
\cline { 2 - 3 } & $17^{\circ} 1^{\prime}-25^{\circ}$ & $4-$ high inclination \\
\cline { 2 - 3 } & over $25^{\circ}$ & $5-$ very high inclination \\
\hline
\end{tabular}

T a b l e 3. Assessment of geometric parameters for individual trail sections.

\begin{tabular}{|c|c|c|c|c|c|c|c|c|c|c|c|c|c|c|}
\hline \multirow[t]{2}{*}{ Attribute } & \multirow{2}{*}{$\begin{array}{c}\text { Weight } \\
\text { coefficient }\end{array}$} & \multicolumn{13}{|c|}{ Assignment of selected attributes for individual path sections } \\
\hline & & 1 & 2 & 3 & 4 & 5 & 6 & 7 & 8 & 9 & 10 & 11 & 12 & 13 \\
\hline Inclination of the tourist path & 0.7 & 1 & 1 & 1 & 2 & 2 & 1 & 1 & 1 & 1 & 1 & 2 & 1 & 1 \\
\hline Inclination of the terrain & 0.5 & 5 & 5 & 5 & 4 & 5 & 5 & 5 & 5 & 5 & 5 & 3 & 5 & 3 \\
\hline
\end{tabular}

\section{(b) Rock resistance}

The resistance of rocks paving the trail and building its immediate surroundings was evaluated by their mechanical and chemical resistance. Even if the mechanical resistance probably plays the main role in destruction processes of rocks today, the sensitivity of carbonate rocks building the trail to the dissolution by precipitation water makes the assessment of chemical resistance also important. The results of our analysis are summarised in Tables 4 and 5.

\section{(c) Geohazard potential}

The occurrence of geohazards depends on numerous factors like rock lithology, rock exposures, precipitation, and so on. Active geohazards may significantly endanger both the 
environment and safety of tourists, implying the importance of correct assessment of their occurrence and possible activity. This reasoned the assignment of a relatively high weight coefficient (0.7) to this parameter (Tables 6 and 7).

T a b l e 4. Rock resistance of the tourist trail surface according to Klimaszewski (1967).

\begin{tabular}{|c|c|c|c|c|c|}
\hline \multirow[b]{2}{*}{ Weight coefficient } & \multicolumn{4}{|c|}{ Category } & \multirow[b]{2}{*}{ Assignment } \\
\hline & & Age & $\begin{array}{l}\text { Mechanical } \\
\text { resistance }\end{array}$ & $\begin{array}{l}\text { Chemical } \\
\text { resistance }\end{array}$ & \\
\hline \multirow{6}{*}{0.5} & $\begin{array}{l}\text { Ramsau } \\
\text { dolomite }\end{array}$ & Ladinian & $\begin{array}{c}\text { middle } \\
\text { resistance }\end{array}$ & high resistance & $\begin{array}{l}3-\text { middle } \\
\text { resistance }\end{array}$ \\
\hline & $\begin{array}{l}\text { Guttenstein } \\
\text { limestone }\end{array}$ & Anisian & $\begin{array}{c}\text { middle } \\
\text { resistance }\end{array}$ & $\begin{array}{l}\text { middle } \\
\text { resistance }\end{array}$ & $\begin{array}{l}3 \text { - middle } \\
\text { resistance }\end{array}$ \\
\hline & $\begin{array}{l}\text { Wetterstein } \\
\text { limestone }\end{array}$ & Anisian & $\begin{array}{c}\text { middle } \\
\text { resistance }\end{array}$ & high resistance & $\begin{array}{l}3 \text { - middle } \\
\text { resistance }\end{array}$ \\
\hline & Fluvial gravel & $\begin{array}{c}\text { Pleistocene-Ho- } \\
\text { locene }\end{array}$ & low resistance & $\begin{array}{c}\text { middle } \\
\text { resistance }\end{array}$ & $\begin{array}{c}4 \text { - low } \\
\text { resistance }\end{array}$ \\
\hline & Loam & Holocene & $\begin{array}{l}\text { very low } \\
\text { resistance }\end{array}$ & $\begin{array}{l}\text { very low } \\
\text { resistance }\end{array}$ & $\begin{array}{c}5 \text { - very low } \\
\text { resistance }\end{array}$ \\
\hline & Gravely loam & Holocene & low resistance & $\begin{array}{l}\text { very low } \\
\text { resistance }\end{array}$ & $\begin{array}{c}5 \text { - very low } \\
\text { resistance }\end{array}$ \\
\hline
\end{tabular}

T a b l e 5. Assessment of rock resistance for individual trail sections.

\begin{tabular}{|c|c|c|c|c|c|c|c|c|c|c|c|c|c|c|}
\hline \multirow{2}{*}{ Attribute } & \multirow{2}{*}{$\begin{array}{l}\text { Weight } \\
\text { coefficient }\end{array}$} & \multicolumn{13}{|c|}{ Assignment of selected attributes for individual path sections } \\
\hline & & 1 & 2 & 3 & 4 & 5 & 6 & 7 & 8 & 9 & 10 & 11 & 12 & 13 \\
\hline Rock resistance & 0.5 & 5 & 5 & 4 & 4 & 3 & 3 & 4 & 3 & 4 & 3 & 3 & 4 & 5 \\
\hline
\end{tabular}

T a b l e 6. Categories of geohazard potential.

\begin{tabular}{|c|c|c|c|c|c|}
\hline \multirow{2}{*}{$\begin{array}{c}\text { Weight } \\
\text { coefficient }\end{array}$} & \multicolumn{4}{|c|}{ Category: type of geohazard } & \multirow{2}{*}{ Assignment } \\
\hline & Erosion & Rock fall & Sliding & Weathering & \\
\hline \multirow{5}{*}{0.7} & Very prone & Very prone & Very prone & Very prone & $\begin{array}{c}5 \text { - very high geohazard } \\
\text { potential }\end{array}$ \\
\hline & Prone & Prone & Prone & Prone & $\begin{array}{c}4-\text { high geohazard } \\
\text { potential }\end{array}$ \\
\hline & $\begin{array}{l}\text { Middle } \\
\text { prone }\end{array}$ & Middle prone & Middle prone & Middle prone & $\begin{array}{c}3 \text { - middle geohazard } \\
\text { potential }\end{array}$ \\
\hline & Low & Low & Low & Low & $\begin{array}{c}2 \text { - low geohazard } \\
\text { potential }\end{array}$ \\
\hline & Stable & Stable & Stable & Stable & $\begin{array}{c}1 \text { - very low geohazard } \\
\text { potential }\end{array}$ \\
\hline
\end{tabular}

T a b l e 7. Assessment of geohazard for individual trail sections.

\begin{tabular}{|c|c|c|c|c|c|c|c|c|c|c|c|c|c|c|}
\hline \multirow{2}{*}{ Attribute } & \multirow{2}{*}{$\begin{array}{c}\text { Weight } \\
\text { coefficient }\end{array}$} & \multicolumn{13}{|c|}{ Assignment of selected attributes for individual path sections } \\
\hline & & 1 & 2 & 3 & 4 & 5 & 6 & 7 & 8 & 9 & 10 & 11 & 12 & 13 \\
\hline Geohazard & 0.7 & 1 & 2 & 3 & 3 & 3 & 4 & 4 & 2 & 2 & 1 & 2 & 3 & 1 \\
\hline
\end{tabular}


The trail resistance according to the above assessed geologic and geomorphologic structure and geometric parameters can be calculated as follows:

$$
\operatorname{Tr}=C w X \max \times T S a X \max =0.7 \times 4=2.8
$$

On a scale of 0.1 (multiplying the lowest possible weight coefficient with the lowest possible assignment grade) to 5 (multiplying the highest possible weight coefficient with the highest possible assignment grade), the above assessed factors place Suchá Belá in the category of middle resistance (Fig. 3).

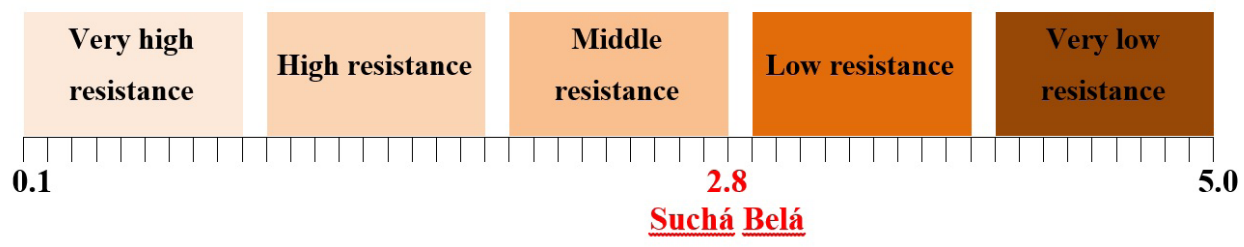

Fig. 3. Categories for site resistance according to geometric parameters, geologic structure, and geomorphologic structure: characteristics of these parameters classify Suchá Belá as a middle resistant site.

T a b le 8. Number of visitors to Suchá Belá in years 2008-2012 (NP administration, 2008-2012).

\begin{tabular}{|c|c|c|}
\hline Year & Date and time of visitor counting & Number of visitors \\
\hline 2008 & $16.7 .2008,8: 00-16: 00$ & 933 \\
\hline 2009 & $19.8 .2009,8: 00-16: 00$ & 900 \\
\hline 2010 & $22.7 .2010,8: 00-16: 00$ & 543 \\
\hline 2011 & $17.8 .2011,8: 00-16: 00$ & 757 \\
\hline 2012 & $24.7 .2012,8: 00-16: 00$ & 788 \\
\hline
\end{tabular}

(d) Tourist flow

The factors considered for determining an acceptable tourist flow were:

1. Tourist path length: $3,800 \mathrm{~m}$.

2. Tourist path width: from $30 \mathrm{~cm}$ to $5 \mathrm{~m}$ (observed during high water level). The width of the path was not directly incorporated into the calculation, yet was considered for the fact that most path sections are too narrow to allow for tourists passing each other on the trail, and thus avoid walking on the adjacent terrain.

3. Average duration of the hike: 2:00 hours.

4. Appropriate distance between tourists: $10 \mathrm{~m}$. This distance relates to tourist density on ladders and steps, where the minimal safety and comfort distance is $5 \mathrm{~m}$. As the walking pace on the access equipment is at least twice slower than on other trail sections, the model distance was set as $10 \mathrm{~m}$ to avoid crowding (mostly beneath the access ladders), which causes intensive trampling disturbance by moving outside the designated areas.

5. Number of tourist visits based on several-year observation by the national park adminis- 
tration: 1,500 in the most frequented hours of tourist visitation (from 8:00 to 16:00). The number of tourist visits to the site is registered by the national park administration by a single-day calculation of visitors in the summer season, from 8:00 to 16:00 (Table 8). To have a safe margin, the number considered for the study was based on assumptions of the national park administration of a marginal reception of 1,500 tourists on a summer day (Slovak Paradise National Park Administration, 2012).

Considering an acceptable distribution of tourists, along with the other above-mentioned factors, the maximum permissible number of visits to the site per day (8 hours) can be calculated as:

$$
T f=\frac{V t}{T d} \times \frac{T l}{R d}=\frac{8}{2} \times \frac{3800}{10}=1520 \text { visitors }
$$

This number can be considered as an indicator based on which the actual reaction of the area to the proposed limits can be specified by long-term terrain research.

\section{Evaluation, discussion, and conclusion}

The first and last sections of the analysed trail (numbered 1 and 13) are located on a slightly uphill terrain with a minimal tendency to geohazard. Also, these sections are generally of sufficient width to allow for an appropriate distribution of tourists. These factors make the alterations caused by trampling negligible in these parts, even though they lead on a very low resistant loam and gravelly loam. This is also due to the fact that these sections are rarely flooded, as opposed to the rest of the trail. The trail sections numbered 2-12 are formed in middle resistant (both to chemical and mechanical load) Wetterstein dolomite rock occasionally covered by wood, tree trunks, and stones deposited by water. These trail parts closely fit a steep exposed terrain with high geomorphologic energy, which is generally a typical setting of high geohazard frequency (Fig. 4).

In classifying the trail resistance (according to geometric parameters, geologic and geomorphologic structure), geohazard was the main factor for determining the site as middle resistant (Tables $1-7)$.

As the trail mostly leads on a stony stream bed resilient to trampling alterations, the overuse from trampling occurs mainly on the trail surroundings. The observation of the trail and its surroundings during the summer months of June and July, with an approximate visitation of 780 tourists daily (Slovak Paradise National Park Administration, 2012), showed no change in the tourist path, and negligible alterations of permanently used alternate paths on the surrounding terrain. Conversely, the increased intensity of tourist visits caused a visibly worsening condition of the narrow terrain belt adjacent to the trail. At the end of July, there were traces of widening of the trail by break down of vegetation cover due to several floods. The uncovered tree roots adjacent to the trail were even more exposed as a result of tourists trying to avoid the stream by walking on the inclined trail side and attaching to them (Fig. 5 ). The surrounding terrain was marked by newly created paths that could change into permanent paths if an additional number of tourists walk on the same terrain before it recovers. 

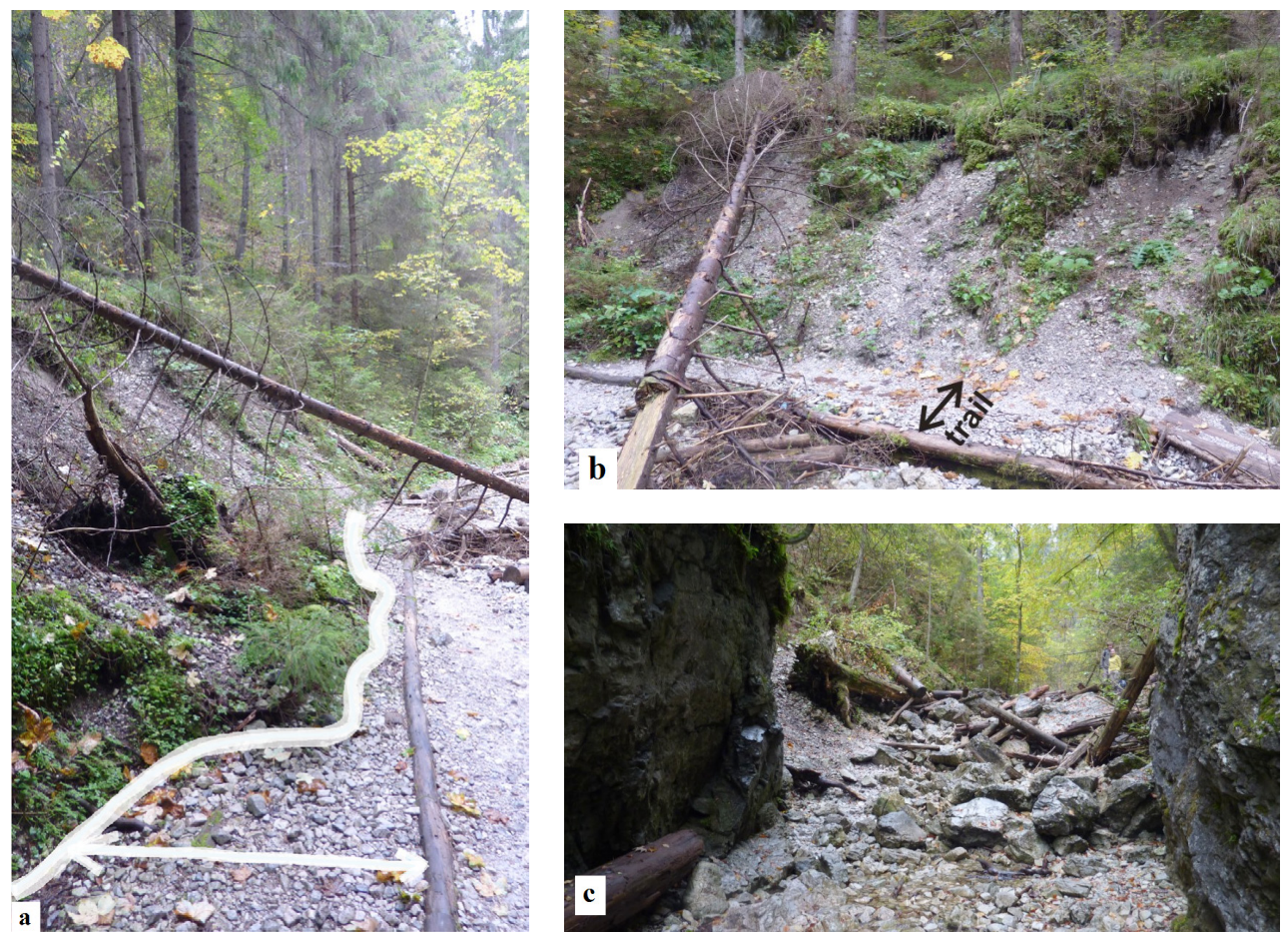

Fig. 4. Examples of geohazard activity directly affecting the trail: (a) trail covered by a slide; (b) small slides flanking the trail; (c) trail covered by rocks fallen from adjacent rock walls.

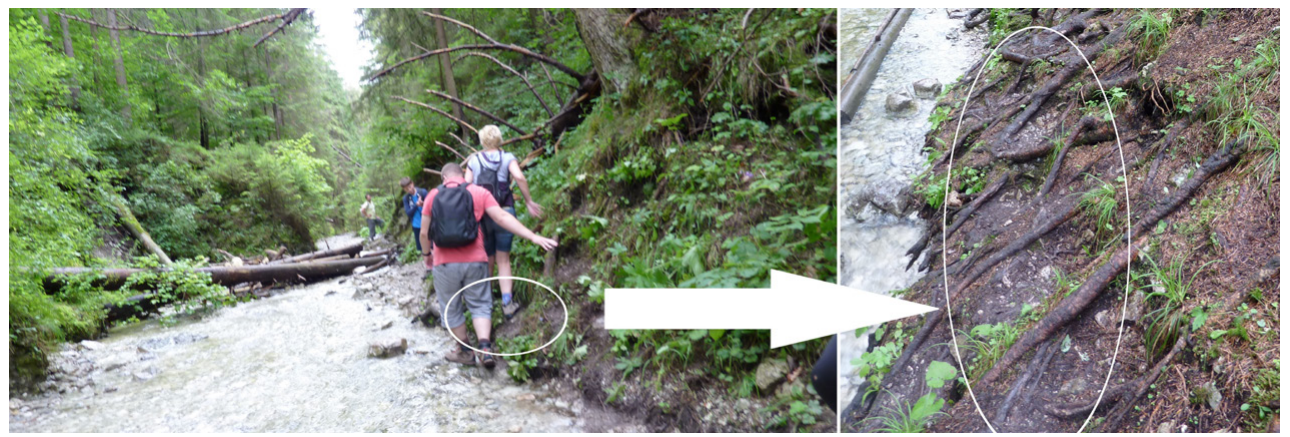

Fig. 5. Alteration of trail surroundings: traces of path widening, break down of vegetation cover, and uncovering of tree roots.

The main reason for off-trail movement, and therefore the key issue influencing the path preservation, is the ephemeral stream leading through the gorge. During floods, the stream transports a considerable amount of weathered rock material, which covers the path and finally is deposited at the confluence of the gorge with axial river Biela Voda. The water often floods the tourist path and damages the access ladders and steps (Fig. 6). 


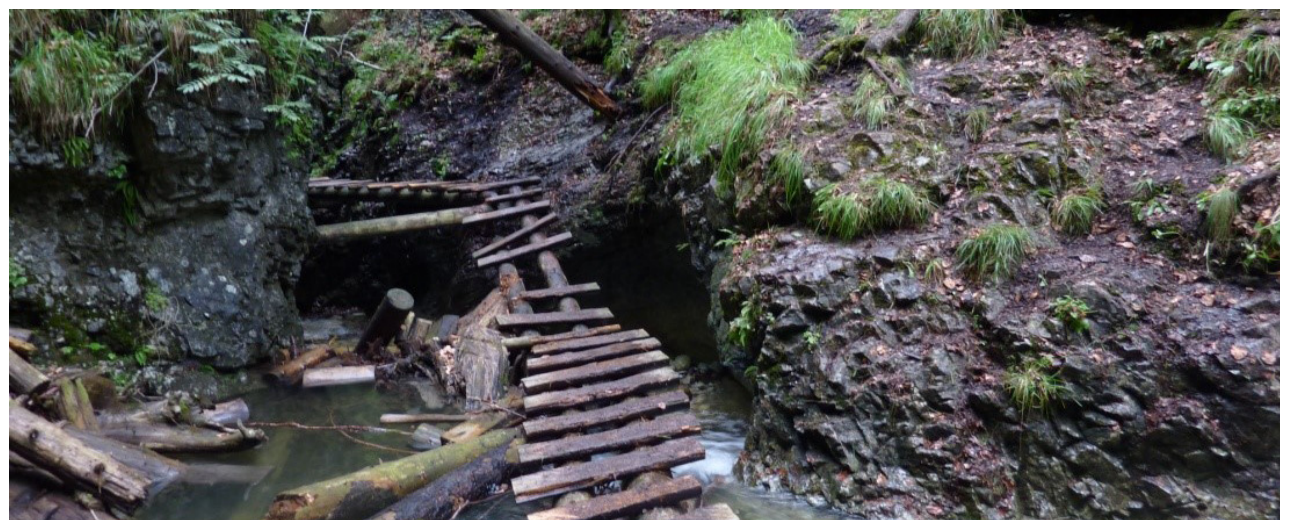

Fig. 6. Damaged wooden ladder after a flood in the gorge Suchá Belá.

To avoid the flooded trail, tourists develop alternative paths on a terrain that is unstable and susceptible to erosion and sliding, particularly at times when the surface is wet (Fig. 7). Such illegal paths attract additional use by tourists when the water level falls.

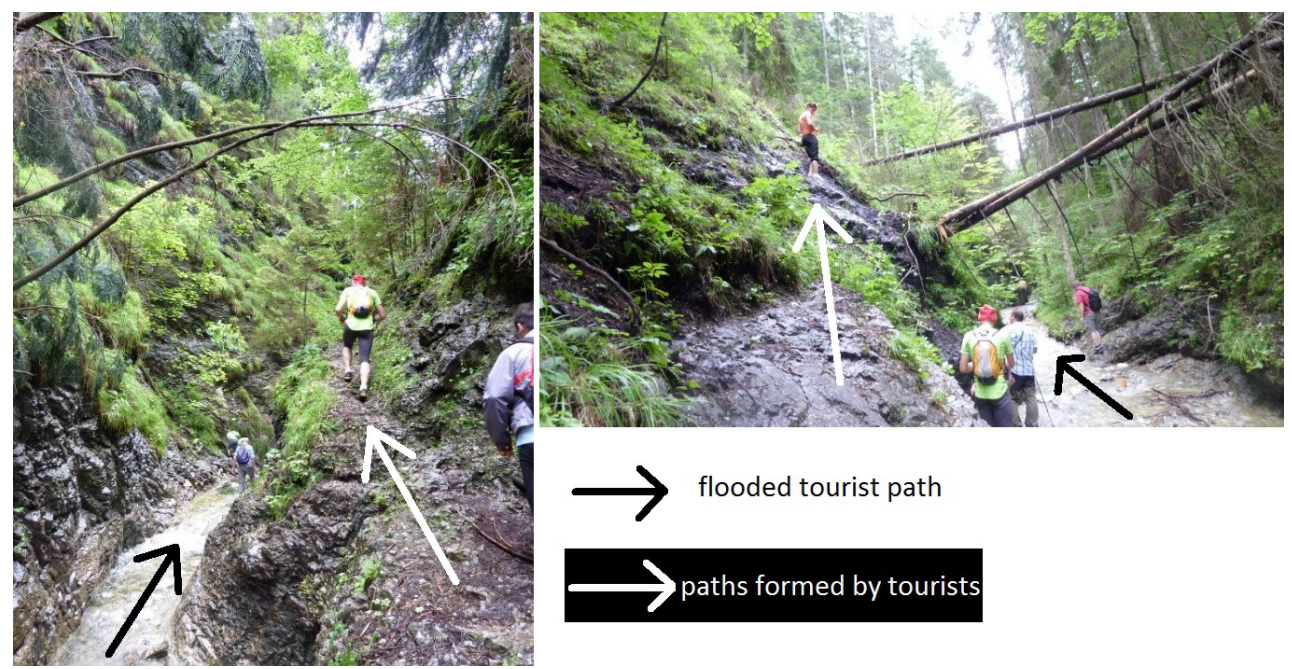

Fig. 7 (a, b). Flooded tourist path causes tourists to form alternative paths on an unstable terrain.

Occasionally, the frequently flooded trail sections are circumvented by elevated ladders placed on the adjacent hillside. These are, however, bypassed by tourists on the loam surface. Another limiting factor of keeping tourists to the designated area is the narrow trail. In the days of heavy visitation, the tourists pass each other by going off trail.

All of the aspects analysed by this study (geometric parameters, geologic and geomorphologic structures, tourist flow, and terrain observation) confirm that the path surface would 
be able to sustain the present tourist load if movement of tourists is limited to the designated path. The anthropogenic degradation of the tourist trail is minimal compared to the alterations of the adjacent terrain (marked by illegal paths, landslides, trail sides with trampled vegetation, and protruding tree roots), which is at a steep angle to the trail and is predisposed to the occurrence of geohazards. Therefore viewing the site as a whole, it can be concluded that intensive trampling disturbance exceeds the carrying capacity of the site due to frequent off-trail tourist movement. It seems that limitation of tourist visits to the site would not necessarily improve the present alterations of the natural environment. The optimal proposed tourist flow to the site (1,520 tourists daily in the regular visiting hours from 8:00 to 16:00) exceeds the actual visitation. The findings rather emphasise an effective delivery of educative interpretation complementing the visiting order of the national park, which would stress the importance to keep tourists on the designated trail.

Based on this, we suggest:

- The optimal layout of the tourist trail limiting the creation of illegal shortcuts is of the utmost importance affecting the preservation of the site. Although very limited by the terrain configuration, studies and workgroups could evaluate possibilities for trail and terrain adjustments (e.g., publications on trail planning and management by Ecological Tourism in Europe and UNESCO MaB, 2007; California State Parks and Rec., 2012; Forest Service Technology and Development Program, 2007; International Biking Association, 2012).

- Clear markings of the designated trail are needed as the trampled paths mislead tourists when the water level falls.

- Monitoring the situation from different perspectives, complemented by statistical and terrain reports, is vital to creating indicators, and can encourage different stakeholders including communities to take action and create preventive measures.

\section{References}

Barančok, P. (1996). Changes in the representation of the selected plant species on the trampling sites of the surrounding of tourist path in the Belianske Tatry Mts (in Slovak). In Eliaš, P. (Ed.), Populačná biológia rastlín IV (pp. 90-92). Bratislava-Nitra: SEKOS.

Barančok, P. \& Barančoková M. (2008). Evaluation of the Tourist Path Carrying Capacity in the Belianske Tatry Mts. Ekológia (Bratislava), 27(4), 401-420.

Bielawska, M. \& Tsermegas I. (2009). Anthropogenic degradation of the tourist trail in the Samaria Gorge (Western Crete). Landform Analysis, 10, 5-10.

California State Parks and Rec. (2012). Trail Maintenance. http://www.foothill.net/fta/work/trailmaint.html.

Coccossis, H. \& Mexa A. (2002). Defining, measuring and evaluating carrying capacity in European Tourism Destinations. From website of the European Commission: http://ec.europa.eu/environment/iczm/pdf/tcca_material. pdf.

Drdoš, J. (1990). Contribution to the issue of land carrying capacity (the case study of Tatra National Park) (in Slovak). Geografický Časopis, 42(1), 3-22.

Ecological Tourism in Europe and UNESCO MaB (2007). The trail planning guide: An insight into the process of planning interpretative trails. Principles and recommendations. From Ecological Tourism in Europe Webhttp://www. oete.de/tourism4nature/results/backdocs/The\%20Trail\%20Planning\%20Guide.pdf.

Forest service technology and development program (2007). Trail construction and maintenance notebook. From Federal Highway Administration Web: http://www.fhwa.dot.gov/environment/recreational_trails/publications/fs_publications/07232806/. 
Hrnčiarová, T. \& Altmanová M. (1999). Impact of the high-mountains landscape by localization of the tourist paths (in Slovak). In T. Hrnčiarová \& Z. Izakovičová (Eds.), Krajinnoekologické plánovanie na prahu 3. tisícročia (pp. 240-247). Bratislava: ÚKE SAV.

Hrnčiarová, T. (2000). High-mountain landscape load due to the hiking trails. Ekológia (Bratislava), 19(2), $222-233$.

Hrnčiarová, T., Miklós, L., Tremboš, P., Kočický, D. \& Weis K. (2002). Ecological carrying capacity of the current land use according to types of abiotic complexes (in Slovak). In L. Miklós \& T. Hrnčiarová (Eds.), Atlas SR (pp. 318-319). Bratislava: MŽP SR, Banská Bystrica: SAŽP.

International Biking Association (2012). Trail building and design. From website of the International Biking Association: http://www.imba.com/resources/trail-building.

IUCN, CORDIO \& ICRAN (2008). Managing Marine and Coastal Protected Areas: A Toolkit for South Asia. IUCN, Gland, Switzerland and Bangkok, Thailand; CORDIO, Kalmar, Sweden; and ICRAN, Cambridge, UK.

Klimaszewski, M. (1981). Geomorphology (in Polish). Warszawa: PAN.

Marion, J.L. \& Wimpey J. (2007). Environmental impacts of mountain biking: Science review and best practices. In P. Weber (Ed.), Managing Mountain Biking: IMBA’s Guide to Providing Great Riding. International Mountain Biking Association, Canada.

Mello, J. et al. (2000). Explanatory notes to the geological map of the Slovak Paradise, Galmus and Hornad Basin, 1:50000 (in Slovak). Bratislava: ŠGÚDŠ.

Midriak, R. et al. (1992). Aspects conditioning the ecological carrying capacity of the National Park Low Tatras. Part 2. Carrying capacity of hiking trails (in Slovak). Správa. Zvolen: LF TU.

Midriak, R. \& Tomagová-Rendeková R. (1993). Destruction and regeneration of the surface of a high-mountain tourist path in Belianske Tatry Mts (in Slovak). Zborník prác o Tanap-e, 33, 87-110.

Sayan, M.S. \& Atik M. (2011). Recreation carrying capacity estimates for protected areas: a study of Termessos National Park. Ekoloji, 20(78), 66-74. DOI: 10.5053/ekoloji.2011.7811.

Slovak Paradise National Park Administration (2012). Detection of number of visitors in the Slovak Paradise National Park (in Slovak). Interný materiál. Národný park Slovenský raj.

State Nature Conservancy - Slovak Paradise National Park Administration (2008). Conservation of Habitat Diversity in Slovak Paradise National Park. Life project final technical report. From website of State Nature Conservancy: / http://www.sopsr.sk/projekty/lifeproject/index_angl.htm.

Thurston, E. \& Reader J. (2001). Impacts of experimentally applied Mountain Biking and Hiking on vegetation and soil of a deciduous forest. Environ. Manag., 27(3), 397-409. DOI: 10.1007/s002670010157.

UNESCO, IUGS \& IGCP (2011). Geohazards: Mitigating the risks. From website of UNESCO:http://www.unesco. org/new/fileadmin/MULTIMEDIA/HQ/SC/pdf/IGCP_THEME3_Geohazards_V2_2011.pdf.

World Wildlife Fund (2004). Slovak Case Study Management Effectiveness Assessment of National Parks using WF's RAPPAM Methodology by World Wildlife Found. From assets.panda.org/downloads/rappam_slovakia_2004_1. pdf. 